\title{
BACTERIOLOGICAL AND PHYSIOLOGICAL RESEARCH STYLES IN THE EARLY CONTROVERSY ON THE NATURE OF THE BACTERIOPHAGE PHENOMENON
}

\author{
by
}

TON VAN HELVOORT *

Historians and sociologists of science take a lively interest in research styles as an analytical concept. ${ }^{1}$ Using the concept of style is a way of emphasizing the role of continuity and tradition in the development of science. To quote Thomas Kuhn, "only investigations firmly rooted in the contemporary scientific tradition are likely to break that tradition and give rise to a new one." 2 On the other hand, the concept of research style is used to argue that there are different and often competing approaches within disciplines, frequently based in research groups or research schools. ${ }^{3}$

The concept of style, now in the form of "thought style", also came into vogue by the translation and republication of Ludwik Fleck's Entstehung und Entwicklung einer wissenschaftlichen Tatsache in which he argued that scientists' observations and their definitions of "facts" are shaped by the thought styles or assumptions shared by "thought collectives". Concepts are supposed to derive their meaning from the existence of a stylistic bond between them, so the thought style determines the formulation of every concept. ${ }^{4}$

* Ton van Helvoort, Department of Health Ethics and Philosophy, University of Limburg, P.O. Box 616, NL-6200 MD Maastricht, The Netherlands.

This study was initiated with the generous support of Dr Wim J. Hornix, Catholic University, Nijmegen, The Netherlands.

1 The concept of style was borrowed from the fine arts, where it refers to cultural patterns. See for instance Ernst H. Gombrich, 'Style', in International encyclopedia of the social sciences, ed. David L. Sills, New York, Macmillan \& Free Press, 1968, pp. 352-61.

2 Thomas S. Kuhn, The essential tension: selected studies in scientific tradition and change, University of Chicago Press, 1977, p. 227. For a compilation of attempts to describe continuity and discontinuity in the development of science see Ian Hacking (ed.), Scientific revolutions, Oxford University Press, 1981.

${ }^{3}$ See for instance Gerald L. Geison, 'Scientific change, emerging specialties, and research schools', Hist. Sci., 1981, 19: 20-40; Joseph S. Fruton, Contrasts in scientific style: research groups in the chemical and biochemical sciences, Philadelphia, American Philosophical Society, 1990.

${ }^{4}$ Thaddeus J. Trenn and Robert K. Merton(eds), Ludwik Fleck: genesis and development of a scientificfact, University of Chicago Press, 1979; Ludwik Fleck, Entstehung und Entwicklung einer wissenschaftlichen Tatsache, Frankfurt am Main, Suhrkamp, 1980; Lothar Schäfer and Thomas Schnelle (eds), Ludwik Fleck: Erfahrung und Tatsache, Frankfurt am Main, Suhrkamp, 1983; Robert S. Cohen and Thomas Schnelle (eds), Cognition and fact: materials on Ludwik Fleck, Dordrecht, Reidel, 1986. The parallel between Fleck's thought collectives and thought styles, and Kuhn's scientific communities and paradigms will be evident.

The existence of a tradition or style in science and its normative role is not easily recognized by most working scientists themselves, although there are exceptions. The renowned virologist and immunologist 
In reviewing recent work inspired by Fleck's ideas, Jonathan Harwood has stated that the concept of thought style can only be used analytically to aid the historian in describing history, but is without any explanatory power. ${ }^{5}$ This conclusion contradicts Fleck's claim that a thought style forces the further development of scientific knowledge into certain directions. In other words, there are limitations to the theoretically limitless variability and negotiability of observations and theoretical notions. In a discussion of the "constraining force" of a thought style, Cohen and Schnelle maintained that Fleck claimed that the thought style structures the working practice of the thought collective, i.e. "both what can and must be considered as a scientific problem, and how this problem is to be dealt with." [Italics in the original.]

In this essay I will discuss a controversy which developed in the 1920 s on the nature of bacteriophages, which are at present conceived of as bacterial viruses. The bacteriophage phenomenon was the observation that an abundant and therefore cloudy bacterial culture lysed within a short time to a clear solution under the influence of a filterable lytic "principle". The interpretation of this phenomenon gave rise to two main opposing positions, represented by Félix d'Hérelle and Jules Bordet, who clashed heavily. In 1917, d'Hérelle proposed the term "bacteriophage" for the lytic principle and was convinced it was to be characterized as a filterable virus which could lyse the bacterial culture. Therefore, this lysis was a virus disease of the bacteria which he named bacteriophagy. In the 1920 s this interpretation was severely criticized by, among others, the bacteriologist and serologist Jules Bordet, who received the Nobel Prize for Medicine in 1919. Bordet's view was that bacteriophagy was linked with the metabolism of the bacterium, while the involvement of a virus was rejected. ${ }^{7}$

My aim is to show that d'Hérelle and Bordet elaborated their respective positions into consistent interpretational contexts or research styles. Like the constraining force of Fleck's conception of thought style, these research styles exerted a constraining force on what was to be studied and how this had to be done. By describing the controversy in detail, a historical example is given of the way in which two research styles limited the interpretive flexibility of experiments. The controversy shows how a

\footnotetext{
Macfarlane Burnet wrote that "Scientific work is of value insofar as it is carried out in accordance with the current tradition of integrity and technical ability and provides results which can be stated in a form that is relevant to the current structure of generalization within the field chosen." See F. Macfarlane Burnet, 'From bacteriophage to influenza virus', in Victor A. Najjar (ed.), Immunity and virus infection, New York, John Wiley \& Sons, 1959, pp. 163-75, on p. 169.

5 Jonathan Harwood, 'Ludwik Fleck and the sociology of knowledge', Soc. Stud. Sci., 1986, 16: $173-87$.

${ }^{6}$ Robert S. Cohen and Thomas Schnelle, 'Introduction', in Cohen and Schnelle, op. cit., note 4 above, pp. IX-XXXIII, on p. XX.

${ }^{7}$ The history of the research into the nature of the bacteriophage phenomenon is discussed in, among others, Paul C. Flu, 'The bacteriophage: a historical and critical survey of 25 years research', Acta Leid. Scholae Med. Trop., 1946, 17: 15-201; André Lwoff, 'Lysogeny', Bact. Revs, 1953, 17: 269-337; Gunther Stent, Molecular biology of bacterial viruses, San Francisco, W. H. Freeman, 1963; Donna H. Duckworth, 'Who discovered bacteriophage?', Bact. Revs, 1976, 40: 793-802; Alan W. Varley, Living molecules or autocatalytic enzymes: the controversy over the nature of bacteriophage, 1915-1925, Ph.D. thesis, University of Kansas, 1986; University Microfilms International, no. 8711282; Charles Galperin, 'Le bactériophage, la lysogénie et son déterminisme génétique’, Hist. Philos. Life Sci., 1987, 9: 175-224; Thomas D. Brock, The emergence of bacterial genetics, Cold Spring Harbor, N.Y., Cold Spring Harbor Laboratory Press, 1990.
} 
particular research style opened up "facts" for discussion which were "closed" within the competing research style. ${ }^{8}$

Félix d'Hérelle's research style will be designated as "bacteriological" while that of Jules Bordet as "physiological". The use of these terms needs to be explained because they differ from the usual disciplinary denotations. The work of d'Hérelle is called bacteriological because he interpreted the bacteriophage as an autonomous living entity infesting bacteria. In this way, he worked within a "thought collective" which regarded filterable viruses as small bacteria or ultramicrobes. This was a conception which was generally held in the study of animal viruses. I have argued elsewhere that, until the late 1940s, workers on influenza thought of the influenza virus as being in many respects just such an ultramicrobe and they worked within a bacteriological paradigm. ${ }^{9}$ But the notion of the nature of a filterable virus as an ultramicroscopic microbe was also current in plant virus research until the $1930 \mathrm{~s}^{10}{ }^{10}$ The work of Bordet is described as physiological in order to indicate that he approached the problem of the bacteriophage by starting from the bacterium. He interpreted his observations on bacteriophagy (including hereditary aspects) as belonging to the physiology of the bacterium.

The use of the terms bacteriological and physiological research styles in bacteriophage research on the basis of one case study may make it look as if I am jumping to conclusions. However, it will be shown elsewhere that, until the $1950 \mathrm{~s}$, bacteriophage research was structured by two thought styles, viz. an exogenous and an endogenous style. ${ }^{11}$ This points to a strong parallel with Gerald Holton's identification of thema/antithema in the development of the physical sciences. ${ }^{12}$

\section{"DISCOVERY" OF THE BACTERIOPHAGE PHENOMENON}

During World War I, Félix d'Hérelle worked at the Pasteur Institute in Paris, where he studied bacillary dysentery. ${ }^{13}$ This form of dysentery, resulting in bloody

\footnotetext{
${ }^{8}$ The interpretive flexibility of experiments is another term for the Quine-Duhem thesis, which states that a theory is underdetermined by experiment. That is to say, all conclusions drawn from experiments can in principle be challenged. Cf. David Gooding, Trevor Pinch and Simon Schaffer, 'Introduction: some uses of experiment', in idem (eds), The uses of experiment: studies in the natural sciences, Cambridge University Press, 1989, pp. 1-27, especially pp. 11-13; Steven Shapin, 'History of science and its sociological reconstructions', in Cohen and Schnelle, op. cit., note 4 above, pp. 325-86, especially note 12 , on pp. 372-3; Jan Golinski, 'The theory of practice and the practice of theory: sociological approaches in the history of science', Isis, 1990, 81: 492-505, on pp. 503-4.

${ }_{9}$ Ton van Helvoort, 'A bacteriological paradigm in influenza research in the first half of the twentieth century', Hist. Philos. Life Sci., forthcoming. An important aspect of this bacteriological paradigm is the concept of specific causation of a distinct disease entity (the ontological conception of disease) by a specific etiological agent. Cf. K. Codell Carter, 'The development of Pasteur's concept of disease causation and the emergence of specific causes in nineteenth-century medicine', Bull. Hist. Med., 1991, 65: 528-48. See also Henk van den Belt and Bart Gremmen, 'Specificity in the era of Koch and Ehrlich: a generalized interpretation of Ludwik Fleck's "serological” thought style', St:ud. Hist. Philos. Sci., 1990, 21: 463-79.

${ }^{10}$ Ton van Helvoort, 'What is a virus? The case of tobacco mosaic disease', Stud. Hist. Philos. Sci., 1991, 22: $557-88$.

${ }^{11}$ Ton van Helvoort, 'The construction of bacteriophage as bacterial virus: linking endogenous and exogenous thought styles', J. Hist. Biol., forthcoming.

${ }_{12}$ Gerald Holton, Thematic origins of scientific thought: Kepler to Einstein (revised edition), Cambridge, Mass., Harvard University Press, 1988.

${ }^{13}$ For biographical information on d'Hérelle see Pierre Nicolle, 'Félix d'Hérelle ', Presse Méd., 1949, 57: 350; Pierre Lépine, 'Nécrologie: Félix d'Hérelle (1873-1949)', Ann. Inst. Pasteur, 1949, 76: 457-60; Jean
} 
diarrhoea, was often found in soldiers at the eastern front. ${ }^{14}$ Despite clinical symptoms, the bacteriological diagnosis was often problematic, as dysentery bacilli were not found. In 1903, Emil de Schweinitz and M. Dorset had claimed that swine fever or hog cholera could not be attributed to the hog-cholera bacillus (now known as Salmonella cholerae-suis) alone. In the laboratory, the disease was contagious only when the presence of a specific filterable virus could be shown. ${ }^{15} \mathrm{D}$ 'Hérelle, therefore, investigated the possibility that in the case of bacillary dysentery also such an additional factor could play a role. For this purpose he filtered the stools of a dysentery patient through an ultrafilter and combined the filtrate with a culture of dysentery bacilli. To activate the mixture he incubated it overnight, and the following morning to his surprise the container was clear instead of containing the expected turbid culture. D'Hérelle concluded that he had discovered a principle which was antagonistic to dysentery bacilli. Such a principle would explain the absence of bacilli observed in some of his patients. ${ }^{16}$

The first results of d'Hérelle's studies were presented by Emile Roux at the French Académie des Sciences in September 1917. ${ }^{17}$ D'Hérelle claimed that the antagonistic principle was filterable, living and organized, and hence a microbe. He thought the living nature of the principle was proved by the possibility of transmitting it in a series of cultures of dysentery bacilli: a very small amount of the ultrafiltrate in a fresh bacterial culture resulted in the same amount of lytic principle as was present in the original lysate. It was possible to transmit the phenomenon endlessly. Another observation was that when a mixture of bacteria and a highly diluted filtrate of a lysed bacterial culture was cultured on a slant (gélose incliné or sloped agar) small circular patches appeared in the bacterial layer. Because, as d'Hérelle stated, a chemical substance could not concentrate itself at a particular spot, the presence of bacteriumfree spots proved the "organized" character of the principle. D'Hérelle called his discovery a microbe which was antagonistic to dysentery bacilli, i.e. an obligatory bacteriophage. $^{18}$

The in vitro antagonistic action of the bacteriophage to a bacillary pathogen immediately suggested that the filterable agent could also play a role in the natural course of bacillary dysentery. In 1918, d'Hérelle concluded that the pathogenicity of dysentery bacilli in infected humans was indeed dependent on the presence of the microbe filtrant bactériophage discovered by him. When he subsequently discovered that the bacteriophage was also present in healthy humans he suggested the general

Théodoridès, 'F. d'Hérelle', in Dictionary of scientific biography, ed. Charles C. Gillispie, 16 vols, New York, Charles Scribner's Sons, 1972, vol. 6, pp. 297-9.

${ }^{14}$ See Georges Bertillon, 'Une épidémie de dysenterie hémorragique dans un escadron de dragons', Ann. Inst. Pasteur, 1916, 30: 141-4; Félix d'Hérelle, 'Sur un bacille dysentérique atypique', ibid., pp. 145-7.

${ }^{15}$ See John M'Fadyean, 'The ultravisible viruses', J. Comp. Path. Ther., 1908, 21: 58-68, 168-75 and 232-42, on pp. 173-5.

${ }^{16}$ For this version of the discovery of the bacteriophage phenomenon see Félix d'Hérelle, The bacteriophage and its clinical applications, London, Baillière, Tindall \& Cox, 1930, pp. 1-4.

${ }^{17}$ Félix H. d'Hérelle, 'Sur un microbe invisible antagoniste des bacilles dysentériques', Compt. Rend. Acad. Sci., Paris, 1917, 165: 373-5.

${ }^{18}$ By using the suffix "phage" $d$ 'Hérelle wanted to indicate that the bacteriophage multiplied at the expense of the bacterium, not that it "eats" the bacterium (cf. the engulfment of bacteria by phagocytes). See Félix d'Hérelle, The bacteriophage and its behaviour, London, Baillière, Tindall \& Cox, 1926, pp. 18-19. 


\section{Bacteriological and physiological research styles}

name Bactériophagum intestinale 1918 for the agent. The part that the bacteriophage played in the development of bacterial infections was to be used by d'Hérelle and many others in the treatment of these diseases. This became known as bacteriophage therapy. ${ }^{19}$

For some years d'Hérelle was the only one who studied the phenomenon he had described, but this changed when Tamézo Kabéshima entered the field. This Japanese researcher, who worked in d'Hérelle's laboratory, received a bacteriophage sample from d'Hérelle. ${ }^{20}$ The irony was that not only did Kabéshima's conclusion on the nature of the bacteriophage contradict that of d'Hérelle, but it also sparked off intense opposition by influential scientists.

To Kabéshima the properties of d'Hérelle's microbe filtrant bactériophage were not those of an organism but of a ferment. On the basis of this dissenting interpretation, he assumed the following mechanism for the dissolution of a dysentery culture. Kabéshima supposed that a gland in the digestive tract secreted a catalyst which dissolved the pathogenic bacteria. Serial transmissibility of the phenomenon was to be explained by the presence of a prodiastase in the microbes, which, under the influence of the catalyst, was set free as a fresh catalyst in the "autolysis" of the bacterium. According to Kabéshima, his former use of the term microbe de d'Hérelle should be replaced by solution de ferment d'immunité bactériolysant. ${ }^{21}$

Kabéshima based his characterization of a bacteriophage as a ferment on two observations which he saw as absolutely contradictory to the hypothesis which had been formulated by d'Hérelle. After being stored for four years at room temperature (remember that Kabéshima studied bacteriophage in d'Hérelle's laboratory) a filtered lysate was still capable of bringing about lysis in a fresh bacterial culture. This contradicted the phenomena of degeneration that were shown by living bacteria if they were stored for a long time. Secondly, Kabéshima had observed that the principle remained active after exposure to temperatures of 65 to $70{ }^{\circ} \mathrm{C}$ in a humid environment. It also resisted the action of antiseptic agents like chloroform, toluene, alcohol and ether, while it was known that such chemicals destroyed the vital activity of cells. The principle discovered by d'Hérelle also retained its activity after exposure to 1 per cent sodium fluoride, while it was known that living fermentative processes were immediately stopped by this agent. ${ }^{22}$

D'Hérelle did not wait long before responding to the position taken by Kabéshima. The question was whether the bacteriophage was an organized or a non-organized ferment, i.e. a ferment figuré, d'un microbe parasite des bactéries or a ferment soluble,

\footnotetext{
${ }^{19}$ Félix d'Hérelle, 'Sur le rôle de microbe filtrant bactériophage dans la dysenterie bacillaire', Compt . Rend. Acad. Sci., Paris, 1918, 165: 970-2; idem, 'Technique de la recherche du microbe filtrant bactériophage', Compt. Rend. Soc. Biol., 1918, 81: 1160-2. On bacteriophage therapy see, for instance, William C. Summers, 'On the origins of the science in Arrowsmith: Paul de Kruif, Félix d'Hérelle, and Phage', J. Hist. Med., 1991, 46: 315-32.

${ }^{20}$ Félix d'Hérelle, The bacteriophage, its role in immunity, Baltimore, Williams \& Wilkins, 1922, p. 145.

21 Tamézo Kabéshima, 'Sur un ferment d'immunité bactériolysant, du mécanisme d'immunité (des maladies) infectieuse(s) intestinale(s), de la nature du dit "microbe filtrant bactériophage" de d'Hérelle', Compt. Rend. Soc. Biol., 1920, 83: 219-21, on p. 221; the additions in brackets are errata, ibid., p. 264.

${ }_{22}$ Tamézo Kabéshima, 'Sur le ferment d'immunité bactériolysant', Compt. Rend. Soc. Biol., 1920, 83: 471-3.
} 


\section{Ton van Helvoort}

d'une diastase. ${ }^{23}$ D'Hérelle's and Kabéshima's differing interpretations were to dominate the controversy on the nature of the bacteriophage for several decades to come: the bacteriophage as a living, filterable virus versus the bacteriophage as a ferment or enzyme. The lines along which d'Hérelle was to defend his position will be discussed more fully later on. But first we will see that not only was d'Hérelle's interpretation of the bacteriophage phenomenon to be challenged, but also his claim to have discovered it. In the course of the priority dispute d'Hérelle changed his definition of bacteriophagy.

\section{PRIORITY DISPUTE AND REIFICATION OF BACTERIOPHAGY}

Jules Bordet, also, defended the theory that bacteriophagy was not to be explained as the consequence of a living ultravirus but as the result of the action of a lifeless ferment. This Belgian scientist, who was to become a powerful opponent of d'Hérelle, received his training at the laboratory of Élie Metchnikoff at the Pasteur Institute in Paris at the end of the nineteenth century. Before his thirtieth year he had done important work in the field of serology and humoral immunity. ${ }^{24}$ In March 1921 , Bordet and his fellow worker Mihai Ciuca announced that they had traced a publication by Frederick Twort which contained the real first description of the d'Hérelle phenomenon. Because of their "souci d'un historique exact" they considered it their responsibility to point out the existence of this article dating from 1915. According to Bordet and Ciuca the priority of the English scientist could not be doubted: "Sans vouloir diminuer l'intérêt des constatations de d'Hérelle, nous avons cru que c'était un devoir de reconnaître l'incontestable priorité de Twort dans l'étude de cette question." 25 As is pointed out by Alan Varley, it was not Bordet who first drew attention to Twort's 1915 article, but the author himself. In a paper called 'Researches on dysentery' - which was totally neglected in bacteriophage researchTwort discussed both d'Hérelle's paper of 1917 and his own of 1915. The work of d'Hérelle seemed a confirmation of his own earlier research. ${ }^{26}$

${ }^{23}$ Félix d'Hérelle, 'Sur le microbe bactériophage', Compt. Rend. Soc. Biol., 1920, 83: 247-9, on p. 249. The dichotomy between the interpretation of the nature of a filterable virus as a living microbe or germ (organized ferment) and as a lifeless ferment endured for more than three decades (see Heinrich Bechhold, 'Ferment oder Lebewesen?', Kolloid-Zeitschr., 1934, 66: 329-40 and idem, 1934, 67: 66-79). Martinus W. Beijerinck's conception of a contagium vivum fluidum for tobacco mosaic virus (TMV) can be regarded as a hybrid between these two classical positions, but not many scientists took his point of view (see Helvoort, op. cit., note 10 above). It is to be noted that Pasteur used the phrase "theory of germs" (théorie des germes) for the first time in 1876; before then he spoke of the "theory of organized ferments". See Carter, op. cit., note 9 above, p. 530, footnote 9 .

${ }^{24}$ For biographical information on Jules Bordet see Paul Bordet, 'L'Institut Pasteur de Bruxelles', Ann. Inst. Pasteur, 1950, 79: 507-20; J. Beumer, 'Jules Bordet 1870-1961', J. Gen. Microbiol., 1962, 29: 1-13; Jean Vieuchange, 'Jules Bordet', in Gillispie, op. cit., note 13 above, 1973, vol. 2, pp. 300-1. See also A. Petterson, 'Presentation speech Nobel Prize physiology or medicine 1919', in Nobel lectures: physiology or medicine 1901-1921, Amsterdam, Elsevier, 1967, pp. 519-22; Anna-Brita Laurell, 'Jules Bordet - a giant in immunology', Scand. J. Immunol., 1990, 32: 429-32. Jules Bordet did not present a Nobel Lecture because of his visit to the United States of America.

${ }^{25}$ Jules Bordet and Mihai Ciuca, 'Remarques sur l'historique de recherches, concernant la lyse microbienne transmissible', Compt. Rend. Soc. Biol., 1921, 84: 745-7, on p. 745 and p. 747 respectively. Cf. Félix d'Hérelle, 'Sur l'historique du bactériophage', ibid., 1921, 84: 863-4.

${ }^{26}$ Frederick W. Twort, 'Researches on dysentery', Brit.J. exp. Path., 1920, 1: 237-43, on p. 237; discussed in Varley, op. cit., note 7 above, pp. 249-55. 


\section{Bacteriological and physiological research styles}

Frederick Twort was superintendent of the Brown Animal Sanatory Institution, which was associated with the University of London. For his study on the nature of filterable viruses Twort had used cheap and widely available raw material, i.e. glycerinated vaccinia pulp. ${ }^{27}$ In an attempt to cultivate vaccinia virus on a lifeless nutrient he observed that colonies of micrococci (staphylococcus), which were present as a contamination in glycerinated vaccinia pulp, underwent a change which he designated as "glassy and transparent". This change could be transmitted with an inoculation needle to colonies of normal micrococci. The active principle could be transmitted in series and was found to be filterable through the finest ultrafilters. Twort had proposed three possibilities for the nature of the principle, though he did not express any preference as to which one would be the most probable. The principle could be an ultramicroscopic virus, a product of the microbe or a stage in the life cycle of the bacterium. The first option represented the position taken by d'Hérelle, while the second, the endogenous origin of the principle, was related to Bordet's position. It seems likely that Jules Bordet used Twort's independent and earlier publication to reaffirm the position that he himself was defending. ${ }^{28}$

Within the scientific community priority is important, ${ }^{29}$ and d'Hérelle used two strategies to try and safeguard his priority in discovering the bacteriophage. First, he attempted to antedate his findings. In the English translation of his first monograph on bacteriophagy, d'Hérelle added a new chapter on the nature of the bacteriophage, in which he claimed to have already observed bacteriophagy in his studies of locusts on which he had reported since 1911. These appeared to be resistant to a coccobacillus with which d'Hérelle had tried to control a locust pest. ${ }^{30} \mathrm{He}$ ascribed this resistance to an "antagonistic principle", in other words the bacteriophage. However, this reconstruction of his first observation of bacteriophagy aroused suspicions about d'Herelle's honesty in the question of priority. ${ }^{31}$

As a second line of defence, d'Hérelle stated that bacteriophagy was to be distinguished from other phenomena which showed superficial similarities to bacteriophagy. However, studies by E. H. Hankin (1896), the later work of R. Emmerich and O. Löw (1901) and that of E. Gildemeister (1917) could have been

\footnotetext{
${ }^{27}$ Frederick W. Twort, 'An investigation on the nature of ultramicroscopic viruses', Lancet, 1915, ii: 1241-3. Vaccinia pulp is the material which is scraped off from the carved skin after infection with vaccinia virus. Such pulp is a mixture of epidermal cells, leukocytes, plasma, hair, bacteria and vaccinia virus. The larger parts were removed, after which glycerin was added to stabilize the virus and control the multiplication of bacteria.

${ }^{28}$ Cf. Duckworth, op. cit., note 7 above, p. 798.

${ }^{29}$ Robert K. Merton, 'Priorities in scientific discovery: a chapter in the sociology of science', Am. soc. Rev., 1957, 22: 635-59; reprinted in Norman W. Storer (ed.), The sociology of science: theoretical and empirical investigations, University of Chicago Press, 1973, pp. 286-324.

${ }^{30}$ D'Hérelle, op. cit., note 20 above, p. 144. Cf. Félix d'Hérelle, 'Sur une épizootie de nature bactérienne sévissant sur les sauterelles au Mexique', Compt. Rend. Acad. Sci., Paris, 1911, 152: 1413-15; idem, 'Le coccobacille des sauterelles', Ann. Inst. Past., 1914, 28: 280-328 and 387-407; idem, 'Sur le procédé biologique de destruction des sauterelles', Compt. Rend. Acad. Sci., Paris, 1915, 161: 503-5.

${ }^{31}$ Cf. Duckworth, op. cit., note 7 above, p. 799. The English edition of 1926 first told the full story of d'Hérelle's observation of the bacteriophage phenomenon in 1910. See d'Hérelle, op. cit., note 18 above, pp. 1-2. According to Macfarlane Burnet the bacteriophage phenomenon was so striking that "in all probability bacteriophage plaques must have been seen occasionally on urine cultures almost from the time when Koch first developed solid jelly-like media for the growth of bacteria." See Macfarlane Burnet, Changing patterns; an atypical autobiography, Melbourne, W. Heinemann, 1968, pp. 53-4.
} 
related to the bacteriophage phenomenon. But none of these scientists had taken the position which d'Hérelle defended so ardently, i.e., that the bacteriophage was a living filterable virus. ${ }^{32}$ The observations reported in 1915 by Twort, who had suggested the possibility of a viral nature, were evaluated by d'Hérelle as not belonging to the bacteriophage phenomenon. He contested the conclusion of André Gratia and D. Jaumin, who claimed that the phenomena of Twort and d'Hérelle were identical. D'Hérelle concluded from their study that staphylococci were indeed susceptible to bacteriophage, but also that they showed a second disease, i.e. the phenomenon described by Twort. This consisted of a "fragmentation" of the bacteria resulting in a residue which could be stained with Giemsa, while bacteriophagy was expressed as a "total dissolution" of the bacteria. D'Hérelle underlined his conclusion on the nature of the Twort phenomenon with the same rhetorical device that he had used in 1917 , i.e. the reification of a phenomenon by giving it a name. D'Hérelle described such a fragmentation of cocci as bacterioclysis. ${ }^{33}$

A decade after the rediscovery of Twort's article, feelings on the conflict about the identity of the two phenomena still ran high. Over the years the tension between d'Hérelle and André Gratia had come to a head and the latter was inclined to accord Twort almost total priority: “. . . Twort avait pratiquement tout vu et tout pensé sur le bactériophage et n'avait oublié qu'une chose: lui donner un nom." 34 In 1931 d'Hérelle proposed that an arbitral committee decide the question by performing an experiment with Gratia's consent. Paul Flu attended the experiment on behalf of d'Hérelle, while Gratia was represented by Ernest Renaux. The committee concluded that the phenomenon described by Twort could be obtained with staphylococci, resulting in transparent particles which could be coloured with Giemsa red. Because these particles were characterized by their (bacterial) sterility, their multiplication and the serial transmissibility of the phenomenon, it was concluded that the Twort phenomenon did indeed belong to bacteriophagy. In 1938 d'Hérelle admitted that the two phenomena were identical, but he pointed out that the Twort phenomenon was very rare. ${ }^{35}$

The combination of doing experiments and negotiating the question of how to perform and evaluate them produced a consensus about the identity of the Twort and the d'Hérelle phenomena. This established the priority of Twort, a point of view that

\footnotetext{
32 See d'Hérelle, op. cit., note 18 above, pp. 5-13. According to d'Hérelle neither the work of R. Emmerich and O. Löw (1899) on autolysis of B. pyocyaneus, nor the autolysis of B. anthracis which had been studied by Gamaleya (1899) and later by G. Malfitano (1900) were examples of bacteriophagy. The work of Gamaleya is discussed in David Bardell, 'An 1898 report by Gamaleya for a lytic agent specific for Bacillus Anthracis', J. Hist. Med., 1982, 37: 222-5.

${ }^{33}$ André Gratia and D. Jaumin, 'Identité du phénomène de Twort et du phénomène de d'Hérelle', Compt. Rend. Soc. Biol., 1921, 85: 880-1; 'Bacterioclysis: the Twort phenomenon', in d'Hérelle, op. cit., note 18 above, pp. 13-18, on p.16.

34 André Gratia, 'Le phénomène de Twort et la bactériophagie; dernière réponse à M. d'Hérelle', Ann. Inst. Pasteur, 1931, 47: 243-4, on p. 244.

${ }^{35}$ Félix d'Hérelle, 'Le phénomène de Twort et la bactériophagie', Ann. Inst. Pasteur, 1931, 47: 470-1; Paul C. Flu and Ernest Renaux, 'Le phénomène de Twort et la bactériophagie', ibid., 1932, 48: 15-18. In 1938 d'Hérelle wrote about the identity that the "phénomène vu par Twort est une manifestation, extrêmement rare, de la bactériophagie." See Félix d'Hérelle, Le phénomène de la guérison dans les maladies infectieuses, Paris, Masson, 1938, p. 15.
} 


\section{Bacteriological and physiological research styles}

had already been accepted by many bacteriologists in the early $1920 \mathrm{~s} .{ }^{36}$ But it was equally important that in the priority dispute it was decided what was to be regarded as the action of a bacteriophage and what was not. Until the arbitral experiment, d'Hérelle defined it as the total dissolution of a bacterial culture while after the consensus was reached the scope of the phenomenon was widened. Lysis of staphylococci which left bacterial debris also had to be classified as bacteriophagy, because the consensual criteria were sterility and multiplication of the principle and the serial transmissibility of the phenomenon. The point of view that the bacteriophage phenomenon also included other observations apart from the rapid and total dissolution of bacteria, advocated by d'Hérelle as the preferred experimental model, was emphasized in the work of Jules Bordet. ${ }^{37}$

\section{D'HÉRELLE'S INTERPRETATION FURTHER CRITICIZED}

The phenomenon studied by Jules Bordet and Mihai Ciuca, which was linked to that described by d'Hérelle, was presented at the Belgian Sociéte de Biologie on 9 October $1920 .{ }^{38}$ They had injected guinea pigs three or four times, at intervals of a few days, with a culture of Bacillus coli (later renamed Escherichia coli) in the peritoneum. When peritoneal fluid was subsequently removed with a syringe, this was found to contain many leukocytes. Bordet and Ciuca had then found that when this exudate was mixed with a normal culture of $B$. coli the latter bacteria underwent a change. They got an "autolytic power" which could be transmitted to a fresh bacterial culture. A minute quantity of the lysate was sufficient to bring about this lytic power. The lytic principle was not isolated by filtration, as d'Hérelle had done, but by heating the exudate to 60 to $65^{\circ} \mathrm{C}$, killing the bacteria but leaving the autolytic principle active. In this way, Bordet and Ciuca claimed to have isolated the same phenomenon as that reported by d'Hérelle, which was present as an active principle in a filtrate of stools. Thus, their claim that they had observed the same phenomenon as d'Hérelle's bacteriophagy was not based on performing the same isolation technique but on a partial overlap of the observed phenomena, i.e. the serial transmissible lysis of a bacterial culture. The great difference in experimental design between the studies of d'Hérelle and the experiment of Bordet and Ciuca may prompt the question as to why the latter studied d'Hérelle's phenomenon in this way. Three aspects of d'Hérelle's and Kabéshima's publications could have led to this, aspects which impinged on the

\footnotetext{
${ }^{36}$ At the 19th annual meeting of the British Medical Association, held in July 1922 in Glasgow, it was concluded that "it was the almost unanimous opinion of those who took part in the discussion ... that the Twort and d'Hérelle phenomena are identical.... though d'Hérelle cannot be given priority in the discovery of the phenomenon, he undoubtedly deserves credit for having awakened a lively interest in the question raised ...'. See Anon., 'The discussion on bacteriolysis', Brit. med. J., 1922, ii: 313-14, on p. 313.

${ }^{37}$ In 1939 in a review of bacteriophagy, Friedrich Hoder wrote that bacteria could undergo a broad range of changes under the influence of bacteriophage: "die von mehr oder weniger weitgehenden Veränderungen ihrer äußeren Gestalt und ihrer Eigenschaften bis zur völligen Vernichtung in Form einer spurlosen Auflösung gehen." See Friedrich Hoder, 'Bakteriophagen', in E. Gildemeister, E. Haagen and O. Waldmann (eds), Handbuch der Viruskrankheiten, Jena, Gustav Fischer, 1939, vol. 2, pp. 686-713, on pp. 686-7.

38 Jules Bordet and Mihai Ciuca, 'Exsudats leucocytaires et autolyse microbienne transmissible', Compt. Rend. Soc. Biol., 1920, 83: 1293-5; idem, 'Le bactériophage de d'Hérelle, sa production et son interprétation', ibid., pp. 1296-8.
} 
study area in which Bordet was a recognized expert, viz. serology or humoral immunity. Therefore, a brief summary of Bordet's serological work around the turn of the century is appropriate. ${ }^{39}$

In the last decade of the nineteenth century an injection of bacteria into the peritoneum of a small laboratory animal was a standard method in immunological research. ${ }^{40}$ In the mid-1890s Bordet used this experimental system to replicate and investigate further an observation that had been described by Richard Pfeiffer in 1894. Pfeiffer had observed that cholera vibrios underwent a granular transformation in the peritoneal cavity of actively or passively immunized animals. He supposed this to be a "vital" action which would occur only in living animals and thus had to be distinguished from the bactericidal effect shown by cholera serum in vitro. In 1895 , Élie Metchnikoff showed that the granular transformation could also be obtained in vitro by mixing the vibrios with cholera serum and adding peritoneal exudate of a normal guinea pig. In the same year Bordet brought this investigation one step further by showing that granular transformation could be obtained in vitro if one used fresh cholera serum or when fresh serum of a non-immunized animal was added to old or heated cholera serum. Bordet concluded from this that the transformation of the cholera vibrio was caused by the action of two substances: one heat-resistant antibody (substance sensibilisatrice), which was found only in immunized animals, and a heat-labile substance (alexine) which was present in both immunized and non-immunized animals.

In 1898 Bordet published his research, in which he claimed that immunization could be used to obtain a hemolytic serum, i.e. a serum which could lyse blood cells of another animal species. Like the serum that transformed bacteria, it was dependent on a heat-resistant specific component and a heat-susceptible non-specific component. Bordet developed this parallel between sera against bacteria and red blood cells into the complement fixation test, in which hemolysis was used as an indicator system for the presence or absence of the non-specific complement. In the presence of bacterium and antibody, the complement was exhausted, so no hemolysis could occur, and vice versa. ${ }^{41}$ The parallel between the immunological reactions to

\footnotetext{
${ }^{39}$ For a history of immunology see 'Historical sketch of our knowledge on immunity', in Élie Metchnikoff, Immunity in infective diseases, 1905, repr. New York, Johnson Reprint Corporation, 1968, pp. 505-43; 'The scientific basis of immunology', in William D. Foster, A history of medical bacteriology and immunology, London, W. Heinemann, 1970, pp. 92-126; 'Immunology: cellular' and 'Immunology: humoral', in Hubert A. Lechevalier and Morris Solotorovsky, Three centuries of microbiology, New York, Dover, 1974, pp. 182-209 and pp. 210-59 respectively; 'History of doctrines of immunity', in William Bulloch, The history of bacteriology, 1938, repr. New York, Dover, 1979, pp. 255-83; Debra J. Bibel, Milestones in immunology: a historical exploration, Madison, Wisconsin, Science Tech Publishers, 1988; Arthur M. Silverstein, A history of immunology, San Diego, Academic Press, 1989; Alfred I. Tauber and Leon Chernyak, Metchnikoff and the origins of immunology: from metaphor to theory, New York, Oxford University Press, 1991. For the work of Bordet on immunology see also the literature in note 24 above.

40 The peritoneum was also used for the cultivation of microbes which could not be obtained by inoculation into the usual media. See [Edmond I. E.] Nocard, [Emile] Roux, [Amédée] Borrel, [Alessandro T.] Salimbeni and [E.] Dujardin-Beaumetz, 'Le microbe de la péripneumonie', Ann. Inst. Pasteur, 1898, 12: 240-62; reprinted as 'The microbe of pleuropneumonia', Revs Inf. Dis., 1990, 12: 354-8. At present the agent of pleuropneumonia is classified as a mycoplasma.

${ }^{41}$ For a discussion of the complement fixation test and the problems of applying it in the Wassermann reaction on syphilis see Bernard Zalc, 'Some comments on Fleck's interpretation of the Bordet-
} 


\section{Bacteriological and physiological research styles}

bacteria and those to red blood cells from foreign species added to the characterization of the granular transformation as a bacteriolytic process. We can now return to the question of what prompted Bordet to study the d'Hérelle phenomenon.

The initial motivation for Bordet and Ciuca could have been that they wanted to investigate the role of leukocytes in the phenomenon, since Kabéshima had suggested that these cells could be the cause of the bacteriolytic phenomenon. As a consequence of the invasion of pathogenic bacilli, cases of dysentery showed many leukocytes in the watery stools. The technique used by Bordet and Ciuca, the intraperitoneal injection of bacteria in a guinea pig, was a standard technique for obtaining an exudate rich in leukocytes. Secondly, the transmissible lysis observed by d'Hérelle could be related to the bacteriolytic and hemolytic phenomena studied by Bordet. ${ }^{42}$ This was also suggested by Kabéshima's remark that bacteriophagy was a form of autolysis perpetuated by the presence of a prodiastase. Another motive that may have contributed to Bordet's study of the d'Hérelle phenomenon was that d'Hérelle claimed an important role for bacteriophages in the defence against and the convalescence from bacterial infections. The previously mentioned bacteriophage therapy was based on this supposed activity of bacteriophage as an exogenous virus parasitizing on the pathogenic microbe. Therefore d'Hérelle's claim for this important role of bacteriophages meant a direct attack on the importance of the mechanisms of humoral immunity and cellular immunity, which were Bordet's chief claim to fame.

However, Bordet's and Ciuca's investigation also fell within Bordet's expertise in a different way. In addition to the recovery of an autolytic principle from an exudate rich in leukocytes, they observed that a lysed bacterial culture was not totally sterile (in the bacteriological sense of the word). Although the remaining microbes developed only very slowly in broth extract, it was possible to harvest abundantly growing bacterial cultures on agar. In comparison with the original culture of the $B$. coli strain, such new colonies had totally different characteristics. They were very viscous, shiny, glairy and even liquid. Furthermore, the virulence of this new bacterial variant for the guinea pig was enhanced and the variant bacteria had the power to lyse a normal bacterial culture. The latter property was designated by Bordet and Ciuca as lysogenic. ${ }^{43}$ Bordet discussed the development of the new bacterial forms within the context of what was known as bacterial variation, a field that was familiar to him.

\footnotetext{
Wassermann reaction in view of present biochemical knowledge', in Cohen and Schnelle, op. cit., note 4 above, pp. $399-406$.

42 The relation between the phenomena of bacteriolysis and hemolysis on the one hand and Bordet's study of the phenomenon of d'Hérelle on the other is also apparent from the title of one of his Herter Lectures at the Johns Hopkins University. In this lecture the leukocytic exudates were, perhaps erroneously, designated in the title as "hemolytic exudates". See Jules Bordet, "Hemolytic exudates and transmissible bacterial autolysis [Lecture III of the Herter Series]', Johns Hopkins Hosp. Bull. 1921, 32: $302-4$.

${ }^{43}$ Bordet and Ciuca, op. cit., note 38 above, pp. 1293-8; see also Bordet, op. cit., note 42 above. For Bordet and Ciuca both the slimy microbe and the lysed bacterial culture were lysogenic. One important aspect of the work of André Lwoff was that he defined lysogeny as a property of an individual bacterium and not as a property of a bacterial culture. See Lwoff, op. cit., note 7 above, p. 274.
} 
Properties of the bacterial variants he had studied were their macroscopic appearances, fermentative properties, virulencies, etc. ${ }^{44}$

According to Bordet, d'Hérelle's phenomenon had to be interpreted within the context of bacterial variation, which he conceived of as an expression of changed bacterial metabolism. This is apparent from his theoretical discussion of these phenomena, which preceded the presentation of the experimental results obtained with the exudate rich in leukocytes. To Bordet and Ciuca, heredity was the transmission of variations, which occurred via two factors, one extracellular and the other intracellular. Each variation depended on a direct factor, which in turn depended on an external one. The intracellular factor had to be transmitted to the progeny, or it would lose its power. If, as Bordet and Ciuca argued, these ideas on microbial variation were applied to transmissible autolysis, then this phenomenon had to be explained as the consequence of a temporary, external cause that induced the microbes to produce a substance which brought about autolysis and which was also transmitted to their descendants. If it was accepted that this substance could diffuse into the medium, then it was clear that the variation was not only hereditary but also contagious. Bordet and Ciuca supposed that the hereditary variation was a disruption of the equilibrium between the assimilation of certain substances and their de-assimilation, and they characterized the transmissible autolysis as a "hereditary nutritional corruption" (viciation nutritive héréditaire). ${ }^{45}$

We have seen that d'Hérelle explained the bacteriophage phenomenon as the result of an exogenous ultravirus which could be isolated from the digestive tract of both patients and normal persons. Bordet interpreted his findings on the basis of his knowledge of lytic processes and of bacterial variation, which he thought to be an expression of the metabolism or physiological state of the bacteria. This represents a dichotomy between an exogenous cause of the bacteriophage phenomenon and an endogenous explanation. This dichotomy can also be found in later controversies on the bacteriophage and in the development of research on plant viruses. As the years passed, d'Hérelle and Bordet would each develop their own experimental system and theory further, thus creating their own research styles.

FÉLIX D'HÉRELLE AND THE BACTERIOPHAGE: A BACTERIOLOGICAL STYLE

In 1921 d'Hérelle's first book on bacteriophagy appeared as a monograph of the Parisian Pasteur Institute, followed a year later by a revised English translation. In

\footnotetext{
${ }^{44}$ See Jules Bordet and [Jan G.] Sleeswijk, 'Sérodiagnostic et variabilité des microbes suivant le milieu de culture', Ann. Inst. Pasteur, 1910, 24: 476-94. For reviews of bacterial variation in the early twentieth century see for instance Felix Löhnis, 'Studies upon the life cycles of the bacteria; Part I: review of the literature, 1838-1918', Mem. Nat. Acad. Sci., 1922, 16(2): 1-252; Joseph A. Arkwright, 'Variation', in A system of bacteriology in relation to medicine, Medical Research Council, London, HMSO, 1930, vol. 1, pp. 311-74. The history of bacterial variation before the Luria/Delbrück era of bacterial genetics is discussed by William C. Summers, 'From culture as organism to organism as cell: historical origins of bacterial genetics', J. Hist. Biol., 1991, 24: 171-90. See also Olga Amsterdamska, 'Medical and biological constraints: early research on variation in bacteriology', Soc. Stud. Sci., 1987, 17: 657-87; idem, 'Stabilizing instability: the controversy over cyclogenic theories of bacterial variation during the interwar period', J. Hist. Biol., 1991, 24: 191-222.

${ }^{45}$ Bordet and Ciuca, op. cit., note 38 above, pp. 1293-5. The presentation of a theoretical discussion before reporting the experimental results makes the conclusions seem more "inevitable".
} 


\section{Bacteriological and physiological research styles}

1926 he published his magnum opus, in both a French and an English edition. ${ }^{46}$ According to d'Hérelle, bacteriophagy was a two-part phenomenon, namely the dissolution of the bacteria and the multiplication of bacteriophages. Bacteriophagy was an infectious disease of the bacterium and because the etiological agent, the bacteriophage, passed through an ultrafilter, it had to be regarded as an ultravirus. In this respect d'Hérelle remained a faithful adherent of the Pasteurian point of view that infectious diseases were caused by living organisms. After all, Louis Pasteur had written: "En résumé, 'tout virus est un microbe'." 47 However, if d'Hérelle had adhered strictly to the Pasteurian point of view he would have had to maintain that the bacteriophage was an ultramicrobe, which was indeed his first conviction. Later on he claimed that the bacteriophage was alive but had to be characterized as a colloidal particle. However, he borrowed more from his illustrious predecessor than the living nature of an (ultra)virus.

The bacteriological work of Pasteur is characterized by his emphasis on infectious, autonomous microbial entities. Furthermore, Pasteur maintained that microbes are characterized by their adaptation to changing environments, resulting in "microbial variation". To Pasteur, one consequence of the variability of microbes was that the qualitative properties of these agents were of prime importance. ${ }^{48}$ Working within the Pasteurian tradition of viewing microbes as autonomous living agents, these basic assumptions made the following methodological requirements necessary for d'Hérelle.

First, he concluded that the quantitative properties of bacteriophagy had to be explained as the results of the multiplication of a living ultravirus, the bacteriophage. As discussed above, the quantitative properties of bacteriophagy could be shown in a liquid by the serial transmissibility of the bacteriophage. ${ }^{49}$ On a solid medium the multiplication of the bacteriophages was visible as plaques or blank spots (taches vierges), without bacteria, in a bacterial layer. These were caused by the lysis of bacteria which had originally grown there. D'Hérelle compared such plaques with bacterial colonies on a solid medium, and the bacteriophages could be quantified by

\footnotetext{
${ }^{46}$ Félix d'Hérelle, Le bactériophage; son rôle dans l'immunité, Paris, Masson, 1921; idem, op. cit., note 20 above; idem, Le bactériophage et son comportement, Paris, Masson, 1926; idem, op. cit., note 18 above. For the summary of d'Hérelle's ideas about the bacteriophage and bacteriophagy I have mostly used the English edition of the latter book.

${ }^{47}$ Pasteur Vallery-Radot, Oeuvres de Pasteur, vol. 6, Maladies virulentes, virus-vaccins et prophylaxie de la rage, Paris, Masson, 1933, p. 673; cited in Galperin, op. cit., note 7 above, p. 179. Pasteur here used the term "virus" to mean all infective agents, that is, bacteria, but also those agents which had not yet been isolated and cultivated (e.g. the agent of rabies). For a discussion of the work of Louis Pasteur see for instance René Dubos, Louis Pasteur, free lance of science, 1960, repr. New York, Da Capo Press, 1986; Gerald L. Geison, 'Louis Pasteur', in Gillispie, op. cit., note 13 above, 1974, vol. 10, pp. 350-416; 'Pasteur', in Lechevalier and Solotorovsky, op. cit., note 39 above, pp. 15-62. Roll-Hansen characterized the work of Pasteur on fermentation as a typical example of the physical holism with which Pasteur "defeated reductionist doctrines of spontaneous generation (namely that under appropriate conditions life will arise spontaneously from non-living matter) and the reductionist chemical theories of fermentation." See Nils Roll-Hansen, 'Louis Pasteur-a case against reductionist historiography', Brit. J. Philos. Sci., 1972, 23: $347-61$, on p. 356.

${ }^{48}$ For the importance of the phenomenon of microbial variability in the work of Louis Pasteur see 'Pasteur's work on attenuation of virus', in Bulloch, op. cit., note 39 above, pp. 241-52. For a discussion of "pleomorphism", a former synonym for bacterial variation, see also note 59 below.

${ }^{49}$ See 'Bacteriophagy in a fluid medium', in d'Hérelle, op. cit., note 18 above, pp. 37-75.
} 


\section{Ton van Helvoort}

counting the number of plaques caused by a known quantity of bacteriophage suspension. ${ }^{50}$ In liquid media, bacteriophage could be quantified by a method developed by Pierre Miquel, which was known as the "dilution method". According to d'Hérelle both methods of culturing were useful for making the multiplication of bacteriophages visible and for quantifying it. Comparison of the two methods of counting the corpuscles showed similar results. ${ }^{51}$ The plaques were evidence of the discontinuity, the particle-like character of the bacteriophage. ${ }^{52}$

According to d'Hérelle the qualitative characteristics of bacteriophagy were more important than the quantitative aspects discussed above, and he pointed to his great leader: "We have known since the days of Pasteur that in a bacterial culture each of the organisms presents individual characteristics, chiefly in those attributes dealing with its virulence." 53 Since d'Hérelle regarded the bacteriophage as a living virus with individual properties and capable of adaptation, it is not surprising that he demanded special attention in the study of the bacteriophage for the qualitative properties of the process of bacteriophagy:

... quantity is a negligible factor, the quality of the bacteriophage is the most important feature of the phenomenon. The only influence exerted by the quantity of the bacteriophage principle inoculated is in the time required for the completion of the phenomenon. ${ }^{54}$ [Italics in the original.]

D'Hérelle held the opinion that it was impossible to determine the physicochemical properties which gave matter its living nature. But, he argued, we do know the result of "life", that is the power to assimilate in a heterologous medium and the power to adapt. ${ }^{55}$ In a microscopic entity, assimilation could not be observed directly; only the effect of assimilation could be studied, i.e. the multiplication of the organism. ${ }^{56}$ But mere multiplication was not sufficient, because when a particle had reached a certain size, further growth would always lead to a division into two parts. But as this was just a physical process, d'Hérelle argued, this would not imply life. The

${ }^{50}$ See 'Bacteriophagy upon solid media', in ibid., pp. 76-81. The culturing of bacteria on solid culture media had been introduced by Robert Koch; cf. Arthur P. Hitchens and Morris C. Leikind, 'The introduction of agar-agar into bacteriology', J. Bact., 1939, 37: 485-93.

${ }^{51}$ D'Hérelle, op. cit., note 18 above, pp. 96-9.

52 Ibid., pp. 82-6. The non-molecular notion of a liquid was ridiculed in, for instance, Max Delbrück, 'Bacterial viruses or bacteriophages', Biol. Revs, 1946, 21: 30-40, on p. 38. Cf. Frederick C. Bawden, Plant viruses and virus diseases, 4th ed., New York, Ronald Press, 1964, p. 5.

${ }^{53}$ D'Hérelle, op. cit., note 18 above, note on p. 118.

54 Ibid., p. 57.

55 Ibid., pp. 330-2. D'Hérelle first presented this argument in the way that it is discussed here in Félix d'Hérelle, 'Le bactériophage', Rev. Path. Comp. d'Hyg. Gén., 1923, 23: 1-26. Thus d'Hérelle agreed with Claude Bernard who, in his Leçons sur les phénomènes de la vie communs aux animaux et aux végétaux (Paris, Baillière, 1878), had argued that life could only be characterized. Characteristic properties of life were, according to Bernard, organization, generation, feeding, development and susceptibility to disease and death. See Robert P. Cook and Milda A. Cook, Claude Bernard: phenomena of life common to animals and to vegetables, Dundee, Scotland, privately printed, 1974, pp. 11-18.

56 According to d'Hérelle the problem of quantifying bacteriophages (and the ultraviruses in general) was that it was difficult to determine whether the agent was alive or dead. After all, the bacteriophage was known through its effect, so that there was no difference between a dead bacteriophage and one which had lost its virulence. See d'Hérelle, op. cit., note 18 above, pp. 283-4. 
real criterion for life was the power to assimilate in a heterologous medium. The heterologous character of the bacteriophage, its autonomy, relative to the bacterium on which it multiplied, had in d'Hérelle's opinion been proved by many experiments. 57 The second property which would characterize "life" was the phenomenon of adaptation, a property of bacteriophage which was proved, according to d'Hérelle, by its variability. ${ }^{58}$ D'Hérelle thought that there was only one bacteriophage, which could adapt itself and become virulent to a new bacterial species for which at first it had no virulence. ${ }^{59}$

D'Hérelle endorsed Pasteur's point of view that infectious diseases were caused by living organisms, but at the same time he made an adjustment. On the basis of research on the nature of the bacteriophage he concluded that it was a colloid, either of lipoid nature or of protein nature. Consequently, the phenomena of life were not limited to microbes and cellular entities, a view which was not, however, an original thought at this time. ${ }^{60}$

\section{FOLLOWING IN LOUIS PASTEUR'S FOOTSTEPS}

As is apparent from the outline of d'Hérelle's position given above, he was a scientist who elaborated his hypotheses into complete theories. He felt that ideologically he was following in the footsteps of the great Louis Pasteur. Just like his predecessor, he did not eschew confrontations with more or less famous adherents of opposing theories. It is especially clear from his defence of the Germ theory of infectious disease $^{61}$ that he wished to take over the torch of Pasteur. The corrollary of the confirmation of this theory was Pasteur's rejection of the idea of "spontaneous generation" of microbial life. ${ }^{62}$

${ }^{57}$ Ibid., pp. 333-41.

58 Ibid., pp. $350-4$.

${ }^{59}$ Ibid., pp. 366-9. The idea that there might be only one bacteriophage, which could adapt to new hosts, was named by d'Hérelle the "unicity" of the bacteriophage. This is reminiscent of the pleomorphism of bacteria which was defended in the nineteenth century by botanists, for instance Carl von Nägeli but also Max von Pettenkofer. An extreme form of pleomorphism was expressed as: "cocci could become bacilli, and bacilli, spirilla, as the chance of varying environment might dictate." Cited in L. J. Cole and W. H. Wright, 'Application of the pure-line concept to bacteria', J. infect. Dis., 1916, 19: 209-21, on p. 209. In the last decades of the nineteenth century the concept of pleomorphism was commonly accepted especially in France, inspired by the successes of Pasteur in the attenuation of the virulence of anthrax bacilli and the virus of rabies. Cf. Amsterdamska, 1987, op. cit., note 44 above, p. 669.

${ }^{60} \mathrm{See}$ 'The physical state of the bacteriophage', in d'Hérelle, op. cit., note 18 above, pp. 273-83. D'Hérelle was not original in his claim that there could be non-cellular life. See for instance Felix Löhnis's concept of "symplasm" in Löhnis, op. cit., note 44 above, pp. 166-96. Cited in Amsterdamska, 1991, op. cit., note 44 above, p. 201.

${ }^{61}$ For the history of bacteriology see, for instance, Bulloch, op. cit., note 39 above; William W. Ford, Bacteriology, New York, Paul B. Hoeber, 1939; Raymond N. Doetsch (ed.), Microbiology: historical contributions from 1776 to 1908, New Brunswick, Rutgers University Press, 1960; Thomas D. Brock, Milestones in microbiology, Englewoods Cliffs, N.J., Prentice-Hall, 1961; Foster, op. cit., note 39 above; Lechevalier and Solotorovsky, op. cit., note 39 above; Patrick Collard, The development of microbiology, Cambridge University Press, 1976. For a discussion of the Germ theory in the nineteenth century see also Carter, op. cit., note 9 above.

62 On the controversy on "spontaneous generation" see, for instance, John Farley and Gerald L. Geison, 'Science, politics and spontaneous generation in nineteenth-century France: the Pasteur-Pouchet debate', Bull. Hist. Med., 1974, 48: 161-98. For a criticism on this version of the controversy see Nils Roll-Hansen, 'The death of spontaneous generation and the birth of the gene: two case studies of relativism', Soc. Stud. Sci., 1983, 13: 481-519. 


\section{Ton van Helvoort}

Since d'Hérelle was convinced that bacteriophagy was an infectious disease of bacteria, he saw the opposition to his point of view as the resurrection of the old moot point about whether infectious disease is caused by microbes or is of endogenous origin. After all, his opponents explained the d'Hérelle phenomenon as the result of an endogenous lifeless ferment. As the discussion on the nature of infectious disease cropped up again, d'Hérelle even questioned the insight of his predecessor: "It is indeed certain that Pasteur had too little vision to think that the day would come when the living nature of the ultraviruses would be questioned ...". He felt that it would be necessary to go over the same ground in order to prove once more that the "law announced by the clear genius of Claude Bernard, by Pasteur, and by Koch, is always true, that 'all disease reproducing in series arises from a living germ capable of multiplying in the body'."63 D'Hérelle would, incidentally, not have been sorry to find himself among these famous biologists of the nineteenth century.

D'Hérelle stated that these "dead theories must be killed anew" and claimed that the endogenous interpretation of bacteriophagy advanced by Jules Bordet meant the rebirth of the old endogenous theory of Georg Stahl, which had been mobilized against Pasteur by Justus von Liebig. ${ }^{64}$ Liebig's position is illustrated in the following statement, quoted by Louis Pasteur in 1860:

Brewers' yeast, and, in general, all animal and vegetable matter in putrefaction, carry
over to other bodies the state of decomposition in which they are themselves. The
motion which, due to a loss of equilibrium, affects their own components, is
communicated also to the elements of substances which are in contact with them. ${ }^{65}$

Because d'Hérelle regarded the bacteriophage as living he could not accept that it could arise spontaneously as was concluded by some on the basis of the phenomenon of lysogeny. For d'Hérelle's opponents lysogeny, the "spontaneous generation" of bacteriophage, was an important argument for the endogenous origin but, at the same time, an argument against the living nature of the bacteriophage (vide infra).

Although d'Hérelle defended the Germ theory of infectious disease by all possible means, he argued that another dictum from biology was ready to be discarded. He thought that he had shown that the bacteriophage was living, belonged to the ultra-viruses and could be characterized as a colloidal particle. Therefore the "Cellular theory of life" would have to be replaced by the "Micellar theory of life". D'Hérelle stated that the assertion that the cell was the smallest entity of life had become untenable: "The old adage, all cells are derived from a like cell, should be replaced by all living micellae are derived from the division into two identical parts of an antecedent micella." 66

\footnotetext{
${ }^{63}$ Félix d'Hérelle, Immunity in natural infectious disease, Baltimore, Williams \& Wilkins, 1924, p. 337 and p. 339 respectively.

64 Ibid., p. 339 and p. 262 respectively.

65 Cited in Lechevalier and Solotorovsky, op. cit., note 39 above, p. 22.

${ }^{66}$ D'Hérelle, op. cit., note 63 above, p. 52. Cf. Thomas S. Hall, History of general physiology, 600 B.C. to A.D. 1900, vol. 2, From the enlightenment to the end of the nineteenth century, University of Chicago Press, 1969 , pp. 307-64. According to d'Hérelle the "Cellular theory of life" was adhered to as a dogma, even though it lacked an explanation for the absence of a nucleus in bacteria: "Always under the obsession of the preconceived idea that a living being must necessarily be cellular, that is, constituted of a differentiated protoplasm, many scientists have sought desperately for this nucleus [of bacteria]. [Fritz] Schaudinn was
} 


\section{Bacteriological and physiological research styles}

For Félix d'Hérelle the consequences of the discovery of the bacteriophage were very far-reaching, because of its role in the course of bacterial infectious diseases. Once again, he was following in the footsteps of Pasteur, who had also emphasized the prophylactic and therapeutic applications of his research. ${ }^{67}$ Pasteur had argued that infectious diseases were caused by specific micro-organisms and that attenuation of virulent strains could result in a vaccine to be used to arouse immunity. In this way he had developed vaccines against chicken cholera, anthrax and rabies. Analogous to these uses of the new science of bacteriology, d'Hérelle advanced the use of the newly discovered agent in bacteriophage therapy.

But the discovery of the bacteriophage also had reverberations in the traditional biological and medical sciences: "Suddenly bacteriophagy made its appearance. The structure could not support the added weight of the new facts: it crumbled." ${ }^{28}$ Pathology, hygiene, epidemiology and immunology were the medical disciplines that were to be transformed through the discovery of the bacteriophage. When man or animals were infected by a pathogenic microbe, the course of this infection depended on the battle between the infected macro-organism, the bacterium and the bacteriophage. In d'Hérelle's view, the variability of living organisms and of the defensive reactions of the macro-organism meant that there were no strictly defined infectious diseases but only complexes of symptoms. He therefore agreed with a statement by René Laënnec who, he claims, had said that "we do not have diseases, we have only patients." ${ }^{69}$ But besides pathology, other disciplines like epidemiology and hygiene were also to be transformed by the recognition of the role of the bacteriophage. After all, if the bacteriophage was involved in the convalescence from bacterial infectious disease, it could also be used to control it. The living nature of bacteriophage meant that recovery from bacterial disease was also contagious. From this d'Hérelle drew several conclusions about the measures that had to be taken in an epidemic. One example may suffice here to illustrate the impact d'Hérelle attributed to the bacteriophage in hygienic measures. He argued that in an epidemic one normally boiled drinking water to disinfect it, but that this also destroyed the health-bringing bacteriophage. Therefore he advocated filtering drinking water through an ultrafilter in order to let the bacteriophage do its work in the patient. ${ }^{70}$

In conclusion, it will be clear that d'Hérelle studied the bacteriophage as a living and autonomous infectious entity, with special emphasis on its qualitative properties. Starting from a characterization of the bacteriophage as a filterable microbe, he

unable to find it, and, despite his remark that the nucleus can only be defined morphologically, had advanced the hypothesis of the existence of a 'diffuse nucleus'." See d'Hérelle, op. cit., note 63 above, p. 345. Cf. 'Der Zellkern', in Arthur Meyer, Die Zelle der Bakterien, Jena, Verlag von Gustav Fischer, 1912, pp. 40-74; Thomas D. Brock, 'The bacterial nucleus: a history', Microbiol. Revs, 1988, 52: 397-411.

${ }^{67}$ See for instance 'War and peace of microbes', in Bruno Latour, The pasteurization of France, Cambridge, Mass., Harvard University Press, 1988, pp. 1-150. For the work of Pasteur see also the literature of note 47 above.

${ }^{68}$ D'Hérelle, op. cit., note 16 above, p. vi.

${ }^{69}$ Ibid., p. 107. Cf. Jacalyn M. Duffin, 'The medical philosophy of R. T. H. Laënnec (1781-1826)', Hist. Philos. Life Sci., 1986, 8: 195-219; Knud Faber, Nosography: the evolution of clinical medicine in modern times, 2nd ed., 1930, repr. New York, AMS Press, 1978. The existence of an ontological disease entity is an implicit presupposition of "Koch's Postulates" as they are used in proving the etiological relationship between an etiological agent and a disease. See also note 9 above.

${ }^{70}$ See 'Exogenous immunity: bacteriophagy in vivo', in d'Hérelle, op. cit., note 63 above, pp. 271-307, on p. 307. 


\section{Ton van Helvoort}

changed this conception to one of colloidal nature. Despite this change, the living aspects of bacteriophage, i.e. the properties of assimilation and adaptation, were central in his work. It may be concluded that d'Hérelle's work belonged to a bacteriological research style. In its presuppositions on the nature of the bacteriophage, as well as in the way it was studied and in the way this knowledge was put to practical use, d'Hérelle's research belonged to the Pasteurian tradition. The competing notion, which will be more fully discussed in the following sections, explained the phenomenon described by d'Hérelle as the result of an endogenous process of the bacterium, linked with its metabolism and the generation of bacterial variants.

\section{JULES BORDET, TRANSMISSIBLE BACTERIAL LYSIS AND IMMUNITY}

At the beginning of their work, Bordet and Ciuca attributed the cause of the phenomenon of transmissible bacterial lysis to the leukocytes. These would secrete a ferment which caused a disruption of bacterial metabolism: "perhaps the lytic phenomenon observed was merely the consequence of some immunological process, or, so to speak more precisely, was the result of a special modifying influence exerted by the leucocytes on the micro-organisms." In the experimental model of Bordet and Ciuca, a leukocytic exudate was obtained by an injection of bacteria into the peritoneum, while in the case of dysentery, the situation in which d'Hérelle had first observed the bacteriophage, leukocytes were present in the stools. ${ }^{71}$

It has already been pointed out that Bordet's investigations of the d'Herelle phenomenon were closely related to his expertise in the field of lytic phenomena within the context of serology and immunity. These lytic phenomena were in turn related to processes of digestion by the host and of microbial metabolism. The connection between immunity and digestion already played a role in the work of Bordet's mentor, Élie Metchnikoff. ${ }^{72}$

It may seem from the historiography of immunology that at the end of the nineteenth century there were two opposing notions of the mechanisms of immunity. On the one hand there was the humoral theory, which explained immunity as the result of bactericidal and antitoxic substances in body fluids; on the other hand there was the notion of immunity as a result of the activity of cells, i.e. the phagocytes. Metchnikoff became known for his studies on the role of phagocytes in the protection against infectious diseases, for which he received the Nobel Prize for Medicine in 1908. ${ }^{73}$ Although Metchnikoff had outlined his ideas in the absence of knowledge of the humoral aspects of immunity, the later French "cellular school" did pay attention to humoral factors. This is evident from the very fact that Bordet did his early, epoch-making research on serology in Metchnikoff's laboratory.

\footnotetext{
${ }^{71}$ Jules Bordet, 'Cameron Prize Lecture on microbic transmissible autolysis', Brit. med. J., 1923, i: 175-8, on p. 176. Cf. Bordet and Ciuca, op. cit., note 38 above, pp. 1296-8.

${ }^{72}$ For literature on the history of immunology see note 39 above. Cf. 'A digression on immunology', in Varley, op. cit., note 7 above, pp. 98-107.

${ }^{73}$ See Élie Metchnikoff, 'On the present state of the question of immunity in infectious diseases [Nobel lecture, 1908]', in Nobel lectures, op. cit., note 24 above, pp. 281-300; reprinted in Scand. J. Immunol., 1989, 30: 383-98. It is to be noted that it has recently been argued that Metchnikoff did not conceive phagocytes as "gendarmes" of the organism but as an "independent center of activity, representing in that function its own evolutionary origin". See Alfred I. Tauber, 'The immunological self: a centenary perspective', Perspect. Biol. Med., 1991, 35: 74-86, on p. 77. See also Tauber and Chernyak, op. cit., note 39 above.
} 


\section{Bacteriological and physiological research styles}

In Metchnikoff's Immunity in infective disease we see that a supposed antagonism between humoral and cellular mechanisms of immunity does not do justice to his ideas on immunity. According to Metchnikoff, the phenomena of humoral immunity had to be explained in relation to those of cellular activity: both were expressions of digestive processes, one extracellular (in the body fluids), the other intracellular (in the phagocyte).$^{74}$ Metchnikoff claimed that two large categories of mobile phagocytes or leukocytes, i.e. microphages and macrophages, each had their own soluble ferment. Metchnikoff named these ferments cytases, classified them as trypsins, and regarded them as identical to the alexins or complements of other authors. As long as the phagocytes remained intact, the soluble ferments were not released. However, when the phagocytes were damaged, part of the cytases escaped, a process which he named phagolysis. As a result of this, the serum acquired hemolytic and bactericidal properties. In addition to the cytases, soluble ferments which were in essence intracellular, there were also the fixatives, Ehrlich's amboceptors or intermediary substances, which were humoral. ${ }^{75}$

The mechanism of immunity proposed by Metchnikoff consisted of both chemical and biological processes. The digestion of microbial invaders of the macro-organism took place within the phagocytes under the influence of chemical and physicochemical processes. But before these processes could come into play the phagocytes showed typically biological phenomena such as the perception of "chemiotactic sensations", migration to endangered tissues, ingestion of bacteria and secretion of substances which took care of intracellular digestion. Immunity in infectious diseases could be regarded as a "section of cellular physiology, and especially as a phenomenon concerned in the absorption of micro-organisms. This absorption being carried out by an act of intracellular digestion, the study of immunity comes into the chapter on digestion regarded from the general point of view." 76 [Italics mine.]

To Jules Bordet the substances in serum and antiserum which took care of humoral immunity constituted a subject which deserved further study, regardless of their origin. But it could not be doubted that the substances which were responsible for this "chemical" type of immunity were related to the digestive processes of cellular immunity:

The tendency in the study of immunity has been to harmonize these humoral manifestations with the functions of the phagocytes, which, as Metchnikoff has shown, are both in origin and function the digestive cells, fitted to form substances that digest and destroy alien cells. ${ }^{77}$

\footnotetext{
${ }^{74}$ See 'Summary', in Metchnikoff, op. cit., note 39 above, pp. 54469.

75 Ibid., p. 80 and pp. $549-57$.

76 Ibid., pp. 566-7. Tauber and Chernyak have argued that Metchnikoff's theory of immunity resided on the fundamental notion of the organism as intrinsically disharmonious and striving for harmony. Immunity and pathological inflammation were conceived as based upon "physiological inflammation, mediated by the phagocyte, which was responsible for 'harmonizing' potentially discordant cellular elements". See Tauber, op. cit., note 73 above, p. 76. Cf. 'Preface' in Tauber and Chernyak, op. cit., note 39 above, pp. XIII-XVIII.

77 Jules Bordet, 'Les sérums hémolytiques, leurs antitoxines et les théories des sérums cytolytiques', Ann. Inst. Pasteur, 1900, 14: 257-96; reprinted as 'Hemolytic sera and their antitoxins, and theories concerning cytolytic sera in general', in Studies in immunity by Professor Jules Bordet and his collaborators, collected
} 


\section{Ton van Helvoort}

Bordet interpreted the early results of his study of transmissible bacterial lysis within this context of the "chapter on digestion", more specifically the phenomena of bacteriolysis and hemolysis that were being studied within the science of immunity. Furthermore, transmissible bacterial lysis was definitely related to that of autolysis. Both cells and bacteria were known to undergo a process of degeneration after some time which was called autolysis, autophagy or autofermentation. In 1913 Maurice Nicolle wrote in a review of autolysis that life was embedded in assimilation and degradation:

. . la cellule possède une grande intensité vitale, elle assimile avec énergie et désassimile pareillement. Si l'on vient à supprimer, soudain, l'apport des aliments, on provoque une violente rupture d'équilibre dans le sens de la désassimilation. . . Il en résulte une tendance obligée vers le ramollissement des parties, le flou des images microscopiques, la simplification des constituants moléculaires, c'est-à-dire vers l'autolyse.$^{78}$ [Italics in the original.]

With regard to the processes of hemolysis and bacteriolysis Nicolle wrote that fundamental changes could be observed in albuminous globulins, the environment and lipids. He thought autolysis to be characterized by softening, decoagulation and molecular collapse (l'écroulement moléculaire). ${ }^{79}$ Autolysis was a well-known phenomenon in bacteria, which was visible in an extreme form in pneumococci. These bacteria underwent a remarkable form of autolysis in which all the cells plasmolyzed after 24 to 48 hours and the culture became clear. ${ }^{80}$

There are two reasons for discussing here the background of Bordet's work on immunity. First, as stated above, his work formed the context of his interpretation of bacteriophagy. Second, Félix d'Hérelle's criticism was not only directed against the position Bordet took in the bacteriophage controversy but also against humoral serology in general. D'Hérelle made a distinction between experiments performed by chemists and physicists, and those undertaken by biologists. Because of the enduring adaptation of organisms to their environment, experiments by biologists had to be divided into the natural and the artificial. According to d'Hérelle, the experiments of humoral immunology were artificial because they were performed with animals which were naturally resistant to the infections studied. D'Herelle therefore studied bacteriophage in circumstances he considered natural. He claimed to study natural

and translated by Frederick P. Gay, New York, J. Wiley \& Sons, 1909, pp. 186-216, on p. 206. Bordet reiterated Metchnikoff's conclusion that immunity is "simply an instance of intracellular digestion and entirely a chance and efficient application to animal defense of a primitive function which would exist even if there were no pathogenic organisms in existence." See Gay, ibid., p. 141.

${ }^{78}$ Maurice Nicolle, 'L'autolyse (Étude de biologie générale)', Ann. Inst. Pasteur, 1913, 27: 97-117, on pp. 102-3.

${ }^{79}$ Ibid., pp. 113-15.

80 Joseph M. Dougherty and Anthony J. Lamberti, A textbook of bacteriology and immunology, St. Louis, C. V. Mosby Company, 1946, p. 180. To d'Hérelle, the phenomena of degenerating bacterial cultures were of a fundamentally different nature to bacteriophagy. One important argument was that bacteriophagy was found in young and active bacteria, while autolysis was a phenomenon belonging to old and degenerating cultures. See d'Hérelle, op. cit., note 18 above, pp. 5-6 and pp. 316-17. 


\title{
Bacteriological and physiological research styles
}

infectious diseases. ${ }^{81}$ As an example of the artificial character of humoral immunology, d'Hérelle mentioned the bactericidal effect of rabbit blood on anthrax bacilli, while the rabbit was found to be susceptible to anthrax in nature. A counter-example was the insusceptibility to anthrax of the dog, while dog serum showed no bactericidal action. ${ }^{82}$

With this criticism on traditional humoral immunity, d'Hérelle created a niche for the bacteriophage in the recovery from bacterial infectious diseases. He summarized humoral and cellular mechanisms of immunity as endogenous, while the protection by the bacteriophage was characterized as exogenous. ${ }^{83}$ But the artificial character of humoral immunology was not all that was criticized; the nature of the "bacteriolysis" described by Pfeiffer, Metchnikoff and Bordet was also scrutinized by d'Hérelle:

\begin{abstract}
If there is a history which presents a philosophical significance from the point of view of that which may be called "the history of an error" it is indeed the history of the "antibodies." ... The sensitizer became a "lysin;" the simple fixation of complement to a bacterium, in which nothing further is involved, became "bacteriolysis," and the serum containing the sensitizer must be a "bacteriolytic" serum. The magic of words. No one had ever observed the bacteriolysis of a single bacterium under the influence of a serum, but nevertheless, since then many impassioned controversies have been waged to explain the mechanism of this non-existant phenomenon. ${ }^{84}$ [Italics mine.]
\end{abstract}

D'Hérelle stated that the acceptance of "bacteriolysis" as the very basis of immunity had held back immunology for more than twenty years. It will be obvious that he reserved real lysis of bacteria, without any bacterial debris, for the bacteriophage he had discovered.

${ }^{81}$ Félix d'Hérelle argued that chemists and physicists would always perform "natural" experiments but the "biologist selects the conditions of his experiment. He can perform an artificial experiment if the conditions which he elects are artificial, or he can conduct a true experiment if he carries it out under natural conditions. The first leads to error, the second to truth." In d'Hérelle, op. cit., note 63 above, p. 9.

82 Ibid., p. 230 . However, this difference between the activity of humoral factors in vitro and the susceptibility of an animal in vivo was recognized by immunologists. According to Metchnikoff the absence of a parallel between natural immunity and the bactericidal power of a serum had to be sought in the complexity of the process by which the cytases were set free from the leukocytes, as well as in the changes they underwent when they were distributed in the body fluids. Furthermore, immunity consisted not only of the chemical processes but also of biological components like the chemotaxis of the phagocytes and the ingestion of pathogenic micro-organisms. See Metchnikoff, op. cit., note 39 above, pp. 553-4. For the reception of the idea of natural antibodies by Pfeiffer, Metchnikoff, Bordet, Ehrlich and Landsteiner see Peter Keating and Abdelkérim Ousman, 'The problem of natural antibodies, 1894-1905', J. Hist. Biol., 1991, 24: 245-63.

${ }^{83}$ See 'Natural endogenous immunity: the phagocytic reaction', 'Endogenous acquired immunity: the antitoxic reaction', 'Exogenous immunity: bacteriophagy in vitro' and 'Exogenous immunity: bacteriophagy in vivo', in d'Hérelle, op. cit., note 63 above, pp. 212-25, 226-45, 246-70 and 271-307, respectively.

${ }^{84}$ Ibid., pp. 162-3. See also 'The reactions against colloids: the artificial phenomenon of fixation', in ibid., pp. 121-40. There seems indeed to be a difference between the "granular transformation" of Pfeiffer's phenomenon and the complete lysis of a bacterial culture as a consequence of d'Hérelle's phenomenon. When Bordet discussed the destructive effect of a cytolytic serum on the attacked cell he stated that the lesion varied with the cell involved: "the bactericidal action of a fluid or serum on the cholera vibrio is evidenced both in vivo and in vitro by a granular transformation of the organism. The analogous action of hemolytic sera is detectable in vitro as well as intraperitoneally by a destruction of the corpuscles with a diffusion of hemoglobin." [Italics mine.] See Gay, op. cit., note 77 above, pp. 207-8. 


\section{JULES BORDET AND THE BACTERIOPHAGE: A PHYSIOLOGICAL STYLE}

In the 1920s Bordet changed his ideas on the cause of the phenomenon of transmissible bacterial lysis twice. These modifications, however, only strengthened his view that the phenomenon belonged to the physiological functions of the bacterium. One important reason for his change of mind was the work of $\mathbf{M}$. Lisbonne and L. Carrère. These scientists had observed that when coli or proteus bacteria were brought into contact with Shiga bacilli, the latter would lyse and produce a bacteriophage. Lisbonne and Carrère concluded from this that certain Shiga bacilli could be used as an indicator strain to show lysogenic properties of coli and proteus bacteria. In 1923 Jules Bordet stated that transmissible bacterial lysis had to be explained from a bacterial antagonism, which meant that the necessity of leukocytes had to be abandoned. ${ }^{85}$

Not much later, Bordet once more changed his view. In 1924 he claimed that it was not necessary to have an antagonistic interaction between different species of bacteria. After he had cultured four pure strains of $B$. coli for eight months, three of them appeared to produce principles which could lyse dysentery bacilli of the Shiga type. Because these coli bacteria had had no contact with the dysentery bacilli an antagonism between different species could be excluded as the cause. The explanation he now proposed was based on the phenomenon of bacterial variation. As different variants came into existence, these interacted with each other and in this way influenced the "evolution" of the culture. ${ }^{86}$

The organized, corpuscular nature of the lytic principle was also contradicted by the observation that the number of plaques on a solid medium depended on the quantity of susceptible microbes. If many bacteria were added to a lytic principle the latter seemed to disappear, while incubation with few bacteria resulted, after a period of time, in a lysed and clear solution: "The very slight amount of lytic agent will indeed be distributed between so many microbic individuals that each of them, being not sufficiently touched, will not reproduce the principle." ${ }^{87}$ Bordet regarded this as strikingly contradictory to the viral nature of the principle, because a virus would have to multiply abundantly in the presence of an excess of host organisms.

To the adherents of the endogenous theory of the bacteriophage the existence of lysogeny, the apparently spontaneous generation of the bacteriophage, was a crucial argument supporting their point of view. That the bacteriophage could be a parasite was, according to Bordet, totally impossible, because of the spontaneous creation of the bacteriophage in lysogenic bacteria. D'Hérelle, defender of the viral nature of

\footnotetext{
${ }^{85}$ M. Lisbonne and L. Carrère, 'Antagonisme microbien et lyse transmissible du bacille de Shiga', Compt. Rend. Soc. Biol., 1922, 86: 569-70; Jules Bordet, 'La théorie de l'antagonisme microbien dans la genèse de la lyse transmissible', ibid., 1923, 88: 1211-13. Cf. Flu, op. cit., note 7 above, p. 122.

86 Jules Bordet, 'Apparition spontanée du pouvoir lysogène dans les cultures pures', Compt. Rend. Soc. Biol., 1924, 90: 96-8.

${ }^{87}$ Bordet, op. cit., note 71 above, p. 178. See also Flu, op. cit., note 7 above, p. 34. From this quotation it will be clear that, as far as current knowledge allows, Bordet advocated a somewhat peculiar mechanism for the manner with which a substance exerted its influence on a bacterium. This could probably be due to the fact that he belonged to the "colloidal school", and expressed these ideas in his thoughts on the mechanism of the antigen-antibody reaction. For a general discussion of the latter problem see, for instance, Pauline M. H. Mazumdar, 'The antigen-antibody reaction and the physics and chemistry of life',
} 


\section{Bacteriological and physiological research styles}

the bacteriophage, explained lysogeny as the consequence of a mixed infection by bacterium and bacteriophage. D'Hérelle stated that such a mixture of a bacterium and an antagonistic bacteriophage was possible because bacteria developed resistance against the action of the bacteriophage ${ }^{88} \mathrm{He}$ concluded from the work of Bordet and Ciuca that three types of bacterial colonies were possible: (a) ultrapure colonies consisting of resistant bacteria; (b) contaminated colonies consisting of resistant bacteria and bacteriophages ("mixed cultures"); and (c) ultrapure colonies which consisted solely of susceptible bacteria. D'Hérelle based his conclusion that lysogenic bacteria were mixed cultures on his finding that it was, in principle, possible to separate bacteriophages from the bacteria both in naturally occurring and in laboratory-made mixed cultures and that, therefore, in such cultures "bacteriophage corpuscles represent an impurity, in the bacteriological sense of the word." 89 [Italics mine.]

Lack of reproducibility was an important problem in the study of lysogeny. This was clear in the exchange of bacterial cultures between Bordet on the one hand and Lisbonne and Carrère on the other, in which the strains were constantly checked for lysogeny with the help of an indicator strain. It was found that a non-lysogenic strain from Bordet's collection remained non-lysogenic in his laboratory in Brussels, but became lysogenic after being cultured in the laboratory of Lisbonne and Carrère in Montpellier for one year. ${ }^{90}$

In December 1930 Bordet delivered his Croonian Lecture for the Royal Society of London. He devoted it to bacteriophage theories and it seems likely that he faced an audience which sympathized with the position he had taken in the controversy. After all, he interpreted the bacteriophage phenomenon in the context of bacterial variation and this subject was being extensively studied in England, for instance by Frederick Griffith and Joseph Arkwright. ${ }^{91}$ Bordet discussed several elements from the rival "virus theory", including the question of whether the bacteriophage was

Bull. Hist. Med., 1974, 48: 1-21; Lewis P. Rubin, 'Styles in scientific explanation: Paul Ehrlich and Svante Arrhenius on immunochemistry', J. Hist. Med., 1980, 35: 397-425.

88 'Resistance of the bacteria', in d'Hérelle, op. cit., note 18 above, pp. 182-241, especially on pp. 182-8. Because of the development of resistance by bacteria in the presence of the bacteriophage, d'Hérelle accorded the bacteriophage an important role in the evolutionary development of a bacterial culture. $\mathrm{He}$ interpreted the interaction between bacteria and bacteriophage as analogous to the obligatory symbiosis between an orchid and a fungus which had been reported by Noël Bernard in 1901. Orchids are infected through their endotrophic mycorrhizae and the presence of the fungus may be necessary for the germination of the seed. See ibid., footnote on p. 222. Cf. Alan S. Kay, 'Noël Bernard', in Gillispie, op. cit., note 13 above, 1973, vol. 2, pp. 34-5.

${ }^{89}$ D'Hérelle, op. cit., note 18 above, p. 238. Cf. Jules Bordet and Mihai Ciuca, 'Évolution des cultures de Coli lysogène', Compt. Rend. Soc. Biol., 1921, 84: 747-8. By "ultrapure" d'Hérelle meant that it was a pure bacterial strain, free of bacteriophage corpuscles; see d'Hérelle, op. cit., note 18 above, p. 204.

${ }^{90} \mathrm{M}$. Lisbonne and L. Carrère, 'Sur l'apparition spontanée du pouvoir lysogène dans les cultures pures; à propos d'une note de J. Bordet', Compt. Rend. Soc. Biol., 1924, 90: 265-7.

${ }^{91}$ The occurrence and behaviour of $R$ and $S$ types of bacteria had been studied by, among others, the British researchers Frederick Griffith and Joseph Arkwright. Cf. Joseph A. Arkwright, 'Variation in bacteria in relation to agglutination both by salts and by specific serum', J. Path. Bact., 1921, 24: 36-60; Frederick Griffith, 'The significance of pneumococcal types', J. Hyg., 1928, 27: 113-59. See also the literature on bacterial variation in note 44 above. 
organized, as had been concluded from the existence of plaques. Bordet argued that at least three other hypotheses could also explain the formation of plaques, including the argument that they were the result of variations in the susceptibility of the bacteria: only those bacteria which were the most susceptible would lyse and thus give rise to the bacterium-free spots. ${ }^{92}$ Bordet also signalled properties of the lytic principle which contradicted those of living micro-organisms: ${ }^{93}$ (a) the behaviour of the principle with respect to antiseptics; (b) the lack of a "lag" phase when, after being stored for a long time, the principle was added to a bacterial culture ("If it were a virus, one would expect the principle to require an appreciable time for the recovery of its vital activity, after such a long period of inaction."); (c) the lytic principle could be neutralized with antiserum in which the complement had been inactivated by heating it to $60^{\circ} \mathrm{C}$. The activity of an antiserum against bacteria ("bacteriolytic" serum) required complement as well as antibody. This difference in the neutralizing mechanism between bacteriophage and bacteria led Bordet to the conclusion that, unlike a bacterium, a bacteriophage was not "organized". 94

The serial transmissibility of the lytic principle, a cornerstone of the virus theory of bacteriophage, could, according to Bordet, also be explained without postulating the existence of a virus. The bacteriophage would stimulate the bacterium to produce a principle which was identical to the cause of the production. For such a process, Bordet referred to an analogy from normal physiology, that of blood coagulation. The coagulation of blood could be initiated by the contact with a foreign body but also by thrombin. When blood solidified, a new amount of the coagulating principle, the thrombin, was liberated. Therefore, once thrombin had been formed, the initial factor (the solid foreign body) was no longer needed, because thrombin could cause the formation of more thrombin. ${ }^{95}$

In his Croonian Lecture Bordet also described some crucial experimental work on the basis of which he concluded that it could not be doubted that bacteriophagy was connected with the physiology of the bacteria. It should be noted that Bordet's definition of this bacterial physiology was broad and included the differentiation of a bacterial culture into bacterial variants. He discussed the development of rough and smooth variants ( $\mathrm{R}$ and $\mathrm{S}$ types) of Bacillus coli and the role of weak and strong lytic

The discord over the problem of the classification of bacteriophage as filterable virus or otherwise is apparent in the reception of the book Filterable viruses edited by Thomas Rivers (London, Baillière, Tindall \& Cox, 1928). This contained a chapter on the bacteriophage which, according to Rivers, "caused some furor, because some virologists-particularly some British workers-refused to accept phage as a virus". See Saul Benison, Tom Rivers, reflections on a life in medicine and science, Cambridge, Mass., MIT Press, 1967, p. 438.

92 Jules Bordet, 'Croonian Lecture-The theories of the bacteriophage', Proc. Roy. Soc., London, Ser. B, 1931, 107: 398-417, on pp. 400-1.

93 Ibid., pp. 401-4, especially on pp. 401-2.

94 To d'Hérelle the absence of involvement of complement in the action of antiserum against (ultra)viruses, e.g. bacteriophage, indicated that a different serological mechanism was apparently involved; see 'Immunity against the ultraviruses', in d'Hérelle, op. cit., note 63 above, pp. 349-85.

95 Bordet, op. cit., note 92 above, pp. 405-6. Cf. Jules Bordet and Octave Gengou, 'Recherches sur la coagulation du sang', Ann. Inst. Pasteur, 1903, 17: 822-33. Bordet's diagram of blood coagulation is depicted in Fritz Lieben, Geschichte der physiologischen Chemie, 1935, repr. Hildesheim, Georg Olms Verlag, 1970, p. 309. 


\section{Bacteriological and physiological research styles}

principles (bacteriophages) in this process. ${ }^{96}$ Bordet had isolated a lytic principle which was active against the $S$ type while the $R$ type was relatively insusceptible. This principle he called the weak lytic principle, in contrast to the strong lytic principle which was active against both bacterial types. The term "weak principle", therefore, did not mean that it had a weak activity, but only referred to its "host range". If the weak principle was added to a large quantity of bacteria it could adapt to the $R$ type and become active both against the $S$ and the $R$ forms of the bacteria. It had now become the strong lytic principle. Bordet concluded that the "peculiar characters, the individuality of a given type of microbe, are reflected in the qualities of the principle which it is capable of elaborating".97 This he felt to be contradictory to the supposed autonomy of bacteriophage as a filterable virus. The properties and behaviour of the lytic principles which Bordet regarded as incompatible with the notion of the bacteriophage as a virus were the role of the concentration of the lytic principle, and the individuality of the principles in accordance with the nature of the microbial variant by which it was produced. ${ }^{98}$ On the basis of his experiences, Bordet concluded that bacteriophagy was related to the formation of bacterial variants. It has to be emphasized that Bordet regarded the formation of bacterial variants as a process belonging to their normal physiology. Bacteriophagy, as a mutation phenomenon, was a normal physiological process and the lytic power of a bacterial culture was an index of spontaneous differentiation. Bordet saw no necessity to assume the existence of an exogenous virus:

is it not more rational to think that the virus does not exist, that the intense action of the bacteriophage represents nothing more than the pathological exaggeration of a normal function connected with mutations, and that this lysis is, in reality ... a transmissible autolysis?99 [Italics mine.]

\footnotetext{
${ }^{96}$ On solid medium the $\mathrm{S}$ type of a bacterium consists of intact, shining colonies with smooth borders; in salt solution the bacterial culture is easily suspendible (homogeneous clouding) while growing homogeneously cloudy in broth. By contrast, the $\mathbf{R}$ form grows on solid medium in rough, dull and wrinkled colonies (larger and flatter than the $\mathbf{S}$ colonies); in salt solution the $\mathbf{R}$ type shows flocculation or sedimentation (autoagglutination) while growth in broth results in a flocculent growth with precipitate.

97 Bordet, op. cit., note 92 above, p. 408.

98 Anne-Marie Moulin points out that Bordet's opinion on specificity can more properly be viewed as a continuity of all possible grades. In the immunological domain Moulin indicated the following sequence of adherents in order from strict specificity to non-specificity: Paul Ehrlich-Svante Arrhenius-Karl Landsteiner-Jules Bordet-Ludwik Fleck. See Anne-Marie Moulin, 'Fleck's style', in Cohen and Schnelle, op. cit., note 4 above, pp. 407-19, on p. 412.

99 Bordet, op. cit., note 92 above, p. 417 . Bordet expressed the role of mutant formation as follows: "the total population of a pure culture is the seat of perpetual interreactions between the individuals which compose it. The appearance of the lytic power seems, indeed, to be the index of a spontaneous differentiation, but this power itself contributes to the guidance of evolution in the culture, since it induces modifications in certain receptive types." Ibid., p. 416. André Lwoff characterized Bordet's point of view as: "Everything was physiological heredity." See Lwoff, op. cit., note 7 above, p. 276.

This may be the place to evaluate the work of Frederick Twort in relation to the positions of d'Hérelle and Bordet. From Twort's article on dysentery of 1920 (see note 26 above) it is clear that he, like Bordet, interpreted the bacteriophage phenomenon in the context of bacterial variation or "dissociative phenomena". Twort did not state his ideas about the mechanism which, he thought, underlay this process of bacterial variation. He stated that the observed special forms of dysentery bacilli were "probably not stages in a true life-cycle, as the normal type is not produced in rotation, and it is doubtful if they are
} 


\section{Ton van Helvoort}

The decade of Bordet's research which has been briefly discussed here showed some important changes in his ideas on the cause of bacteriophagy. In 1920 he thought he had to explain the d'Hérelle phenomenon as the result of a product of the leukocytes. Transmissible bacterial autolysis would be an inheritable disturbance of the nutrition, a pathological displacement in the assimilating and degrading processes, of the bacteria. This explanation fitted in with the scheme which had been suggested by Metchnikoff for the role of "digestion" and physiology in mechanisms of immunity. The phenomenon of lysogeny played a dominant role in Bordet's change of position in 1923. He now explained the bacteriophage phenomenon as the result of bacterial antagonism between different bacterial species, though shortly afterwards he pointed to processes of bacterial variation within pure cultures. But although he changed his opinion on the cause of the bacteriophage, he continued to interpret bacteriophagy as an aspect of the physiology of bacteria and his work can be characterized as belonging to a physiological research style. His conception of bacterial physiology did not only comprise those aspects which are now thought of as the biochemistry or physiology of bacteria, but also encompassed what is now called bacterial genetics. ${ }^{100}$

\section{THE CONSTRAINING FORCE OF RESEARCH STYLES}

In the 1920s the discussion on the nature of the bacteriophage phenomenon was characterized by a controversy in which both d'Hérelle and Bordet played important roles on opposing sides. The positions they held were inspired by their background knowledge, their reputations and ambitions, by the way they performed their experiments, by their choice of experimental material, etc. D'Hérelle's research was founded upon his notion that a bacteriophage had to be viewed as an autonomous living entity (although he departed from his early notion that it was an ultramicrobe, instead embracing the view that it was a living micell). Bordet developed his study of bacteriophagy from the science of immunity and the study of the physiology of bacteria. The interpretations of the experiments in these contexts were formed and constrained by the choices that were made from available analogies and metaphors.

mutations. Special types may be produced for performing special work, and types in 'pure culture' may be likened to bees in a swarm." See Twort, op. cit., note 26 above, p. 243. It should be remembered that Twort's 1920 article on dysentery remained unquoted in the field of bacteriophage research (cf. Varley, op. cit., note 7 above, p. 300, footnote 29).

100 The development towards independence of bacterial genetics from bacterial physiology showed itself in the work of Joshua Lederberg. In 1951 he wrote that one had to distinguish the situation of an adaptive response being physiological ("a directed change within each bacterial cell") from that of a change in the composition of a bacterial population ("whereby the genetic composition of the culture is altered by differential rates of growth, death or mutations"). See Joshua Lederberg, 'Inheritance, variation, and adaptation', in Bacterial physiology, C. H. Werkman and Perry W. Wilson (eds), New York, Academic Press, 1951, pp. 67-100, on p. 94. In fact, bacterial physiology was to enter the domain of genetics later on, namely in the "operon model" of enzyme synthesis. In this scheme an operator gene, one or more structural genes and a regulator gene determine the synthesis of the enzymes of a particular catabolic or biosynthetic pathway. For a description of this development see for instance 'Gene expression and regulation' in Brock, op. cit., note 7 above, pp. 265-324. For two case studies of the establishment of bacterial physiology in England see Robert E. Kohler, 'Innovation in normal science: bacterial physiology', Isis, 1985, 76: 162-81; and idem, 'Bacterial physiology: the medical context', Bull. Hist. Med., 1985, 59: 54-74. 


\section{Bacteriological and physiological research styles}

For d'Hérelle the bacteriophage was as central as the microbe was to Louis Pasteur. He attributed to it, among other things, the following properties: retention of individuality (autonomy), which was proved when the bacteriophage multiplied on different microbes; the organized or complex character of the bacteriophage; and some properties shared by all living organisms, namely, multiplication in a heterologous medium and adaptation. Furthermore, d'Hérelle thought the interaction between bacteria and bacteriophage to be characterized by a struggle for life between bacteriophage and bacteria, the course of which was influenced by adaptation (on the part of both the bacteriophage and bacterium). The struggle between an infected macro-organism and a pathogenic bacterium depended on the struggle between bacterium and bacteriophage. As the bacteriophage was living, it was impossible that it could arise spontaneously; therefore, lysogeny had to be explained as resulting from a mixture of a bacterium and a bacteriophage in the bacteriological sense of the word. It is this complex of interrelated presuppositions which is denoted as a bacteriological research style, in the sense that bacteriology stands for the study of (ultra)microscopical and autonomous living entities.

That bacteriophagy was an infectious disease of a bacterial population was to a certain extent contradicted by the short time span in which a cloudy bacterial culture was cleared by the lytic principle. Furthermore, the d'Hérelle phenomenon appeared to be linked to the multiplication of the bacteria because, in order to show bacteriophagy, the bacteria had to be living. ${ }^{101}$ Bordet thought transmissible bacterial lysis to be connected to other lytic phenomena which were known to occur in bacteria. Such phenomena were known from humoral immunology and were related to Metchnikoff's view of the physiological and digestive processes which strive towards the integrity of the macro-organism. Furthermore, lytic phenomena were known from the field of bacterial variation, which Bordet thought to be an aspect of the physiology of bacteria. The latter domain included (auto)lytic phenomena and degeneration of ageing bacterial cultures. Bordet claimed that the lytic principle of transmissible lysis was therefore a product of the bacterium, which arose as a result of a shift in the bacterial metabolism. The presumed parasitic nature of the bacteriophage did not agree with the disappearance of the principle in an excess of bacteria; the lytic principle reflected the bacterial type by which it was produced; lysogeny constituted clear evidence that the bacteriophage had to be of endogenous bacterial origin; the transmissibility of the phenomenon could be explained by reference to autocatalytic processes which were known from physiology. According to Bordet, bacteriophagy had to be regarded as a disturbance of the physiology of the bacterium which also found expression in other properties of bacteria, such as changes in behaviour, fermentative properties and outward appearance of the bacterium. This complex of interrelated presuppositions is denoted as a physiological research style.

But the background knowledge on which the development of these research styles was based did not lead only to constraints at a theoretical level. These styles also dictated the method of execution of relevant experiments and the objects of study

${ }^{101}$ See Robert Doerr, 'Die Entwicklung der Virusforschung und ihre Problematik', in Handbuch der Virusforschung, Robert Doerr and Curt Hallauer (eds), Vienna, Julius Springer Verlag, 1938, pp. 1-125, on p. 20. 
which had to be selected for valid experiments within the respective research styles. For the bacteriological research style pursued by d'Hérelle, virulent bacteriophages had to be used:

To effectively demonstrate the [bacteriophage] phenomenon it is necessary to observe the following conditions: (1) To work with a bacterial species which undergoes a rapid bacteriophagy. Such a one is the Shiga bacillus. (2) To work with a bacteriophage of maximum activity for the bacterium in question. (3) To utilize a very small number of bacteriophage corpuscles, acting upon a large number of bacteria. ${ }^{102}$ [Italics in the original.]

Bordet's physiological research style required the use of weak and strong principles, which were defined on the basis of their host range. Other parameters which constituted the core of Bordet's experimental design were the concentration of the lytic principle, the period of time during which bacteria were exposed to the principle and the changes the bacteria underwent under the influence of bacteriophages. ${ }^{103}$ The bacteriological and the physiological research styles constrained the possibilities of the methods used, as well as the criteria for judging what was to be taken as scientifically proved and what as unproved.

I will argue elsewhere that the controversy in bacteriophage research which has been analysed here, is a specific example of a general dichotomy between exogenous and endogenous thought styles. ${ }^{104}$ Attempts to bridge this were made by, for instance, Eugène Wollman with his concept of "hereditary factors". 105 The work of André Lwoff, who in 1950 developed his concept of "probacteriophage", is generally seen as the formation of consensus between the exogenous and endogenous approaches. However, it should be noted that the exogenous character of the bacteriophage was maintained in his concept of probacteriophage. In the following decade, the gap was finally bridged when it was agreed that the genetic material of bacteriophage controls properties of its bacterial host cell. ${ }^{106}$

102 D'Hérelle, op. cit., note 18 above, p. 117.

103 Cf. Varley, op. cit., note 7 above, pp. 184-6.

104 Helvoort, op. cit., note 11 above.

105 Eugène Wollman, 'The phenomenon of Twort-d'Hérelle and its significance', Lancet, 1935, ii: 1312-14.

106 Salvador E. Luria, 'Bacteriophage genes and bacterial functions', Science, 1962, 136: 685-92. 